\title{
Comunicação
}

[Communication]

\section{Associação entre a presença de anticorpos anti-Leishmania sp. e anti-Neospora caninum em cães de Bauru, SP}

\author{
[Association between the presence of anti-Leishmania sp. and anti-Neospora caninum antibodies in \\ dogs from Bauru, Brazil] \\ H. Greca ${ }^{1,2}$, A.V. Silva ${ }^{2,3}$, H. Langoni ${ }^{2 *}$ \\ ${ }^{1}$ FMVZ - UNESP - Botucatu, SP \\ ${ }^{2}$ Departamento de Higiene Veterinária e Saúde Pública - FMVZ-UNESP - Botucatu, SP \\ Distrito de Rubião Júnior, s/n \\ 18618-000 Botucatu, SP \\ ${ }^{3}$ Universidade Paranaense UNIPAR - Umuarama, PR
}

\begin{abstract}
Neospora caninum é um protozoário, parasita intracelular pertencente ao filo Apicomplexa, classe Sporozoaea e família Sarcocystidae. O seu ciclo de vida é dividido em três estágios infectantes: taquizoítos, cistos teciduais e oocistos. Os estágios de taquizoítos e cistos teciduais são intracelulares e encontrados nos hospedeiros intermediários. Os cistos teciduais são encontrados em tecidos de bovinos e cães naturalmente infectados, mas não foram descritos em cães infectados experimentalmente (Dittri. caninum foi diagnosticada em cães por Dubey et al. (1988), a partir do isolamento do protozoário em cultivo celular em camundongos e em cães inoculados com tecidos provenientes de cães infectados. As principais lesões observadas nos animais inoculados experimentalmente foram encefalomielite, poliradiculoneurite, miosite e meningoencefalite. $\mathrm{O}$ isolamento do $N$. caninum permite o desenvolvimento da reação de imunofluorescência indireta, para o diagnóstico sorológico da neosporose, e um teste imunoistoquímico, para a identificação do protozoário em tecidos, pela produção de soro específico anti-N. caninum (Dittrich, 2002).
\end{abstract}

O cão doméstico é o único hospedeiro definitivo conhecido até o momento. Os hospedeiros intermediários naturais de $N$. caninum são os bovinos, equinos, caprinos, ovinos e cervos, entre outros animais (Dittrich, 2002).

Recebido em 18 de junho de 2008

Aceito em 28 de dezembro de 2009

*Autor para correspondência (corresponding author)

E-mail: hlangoni@fmvz.unesp.br
A infecção induz à produção de anticorpos, e a reação de imunofluorescência indireta é considerada como padrão-ouro. $\mathrm{O}$ antígeno utilizado são os taquizoítos, obtidos em histocultura, fixados inteiros nas lâminas. Podem ser obtidos de cepas de N.caninum isoladas de cães e bovinos, pois não há evidências de que variações antigênicas entre os isolados alterem a eficácia dos testes (Bjerkas et al., 1994).

As leishmanioses são doenças causadas por protozoários digenéticos, pertencentes à ordem kinetoplastida, família Trypanossomatidae e gênero Leishmania, com diferentes espécies. O curso é crônico, com sinais cutâneos, mucocutâneos e sistêmicos. Há três formas de apresentação; leishmaniose visceral ou calazar, a leishmaniose tegumentar e ainda a leishmaniose mucocutânea (Lainson e Shaw, 1987).

Tarantino et al. (2001) observaram a coinfecção cutânea por Leishmania infantum e $N$. caninum em cão jovem, na Itália. Cringoli et al. (2002) descreveram a presença de anticorpos antiLeishmania spp. e anti- $N$. caninum na região de Campania, no sul da Itália, e observaram que a infecção por um destes protozoários aumenta, aparentemente, a susceptibilidade para o outro. A imunossupressão causada pela leishmaniose visceral americana (LVA) pode promover a ocorrência de coinfecções por outros agentes, tais como Ehrlichia, Babesia e Dirofilaria, em áreas endêmicas (Andreotti et al., 2005). 
Considerando-se a importância desses patógenos para os cães, o presente estudo teve o objetivo de verificar, em área endêmica para leishmaniose visceral canina, a possível coexistência de anticorpos anti- $N$. caninum e anti- Leishmania spp.

Foram coletadas amostras de sangue de cães do Centro de Controle de Zoonoses (CCZ) da Prefeitura de Bauru, SP, região endêmica para leishmaniose, independente da suspeita ou não de leishmaniose. Em cada visita ao $\mathrm{CCZ}$, foram obtidas 10 amostras por venopunção da veia jugular, previamente à eutanásia, completando-se 100 amostras em 10 coletas. As amostras foram centrifugadas a 3000 rotações por minuto durante 10 minutos, e o soro distribuído em microtubos identificados e congelados a $-80^{\circ} \mathrm{C}$ até o momento da realização dos exames sorológicos.

A reação de imunofluorescência indireta (RIFI) para a detecção de anticorpos anti- $N$. caninum foi realizada de acordo com Dittrich (2002), considerando-se como ponto de corte o título 25 . Para a titulação, foram realizadas diluições em dobro, 1:50, 1:100, 1:200, 1:400 e 1:800, em casos de positividade na última diluição, e foram avaliadas novas diluições, para obtenção do título final. Para o diagnóstico da leishmaniose visceral canina, utilizou-se também a RIFI de acordo com Camargo (1966). Foram utilizadas amostras de soros controle positivo e controle negativo, e considerou-se como título final a maior diluição do soro que mostrou fluorescência completa na borda de, pelo menos, $50 \%$ das promastigotas para leishmaniose, e de taquizoítos para neosporose utilizados com antígenos nas lâminas de imunofluorescência.

Para a associação dos resultados, utilizou-se o teste exato de Fischer, para calcular a probabilidade de associação das características em análise, ou seja, serem independentes quando o número total de dados é pequeno. Para verificar a existência de correlação entre as frequências absolutas dos títulos para cada uma das doenças, utilizou-se o coeficiente de correlação de Spearmann, medida de correlação não paramétrica, que descreve a relação entre duas variáveis. Ao contrário do coeficiente de correlação de Pearson, o coeficiente de Spearmann não requer a suposição de que a relação entre as variáveis seja linear (Triola, 2005).

A associação dos resultados da pesquisa de anticorpos para as duas enfermidades encontra-se na Tab. 1, e, de acordo com o teste exato de Fischer, $\mathrm{P}=0,41$, há indicação de não haver associação entre os resultados da pesquisa de anticorpos para Leishmania spp. e N. caninum, $\operatorname{com} \alpha=0,05$. Quanto à frequência absoluta dos resultados da RIFI para leishmaniose e neosporose, estas são encontradas na Tab. 2. De acordo com o valor do coeficiente de correlação de Spearmann entre os títulos de anticorpos antiLeishmania spp. e anti- $N$. caninum, $\mathrm{r}=0,0975$, e $\mathrm{P}=0,33$, não houve correlação entre os títulos de anticorpos para os dois patógenos.

Das 100 amostras de soros, 65\% foram positivas para anticorpos anti-Leishmania spp. e 14\% para anticorpos anti-N. caninum, com $10 \%$ de positividade para ambos os parasitas. Não se observou associação entre os resultados, indicando que a presença de anticorpos antiLeishmania spp. não aumenta a probabilidade de coinfecção por $N$. caninum. A soroprevalência de Leishmania spp. é maior quando comparada com a de neosporose. Ressalta-se que as amostras foram obtidas de cães capturados pelo CCZ de Bauru, que desenvolve um serviço de vigilância com a captura de cães errantes, como atividade do programa de controle da leishmaniose adotado no município.

Tabela 1. Associação entre presença de anticorpos anti-Leishmania spp. e anti-Neospora caninum em soros de cães de Bauru, SP, pela reação de imunofluorescência indireta (RIFI)

\begin{tabular}{cccc}
\hline & \multicolumn{2}{c}{ RIFI - Leishmania spp. } & Total \\
\cline { 2 - 4 } RIFI - Neospora & Positivo & Negativo & 14 \\
\hline Positivo & 10 & 4 & 86 \\
Negativo & 55 & 31 & 100 \\
Total & 65 & 35 & 100 \\
\hline
\end{tabular}


Tabela 2. Frequência absoluta de resultados da reação de imunofluorescência indireta na detecção de anticorpos anti-Neospora caninum e anti-Leishmania spp. em soros de cães de Bauru, SP

\begin{tabular}{|c|c|c|c|}
\hline \multicolumn{2}{|c|}{ Leishmania spp. } & \multicolumn{2}{|c|}{ Neospora caninum } \\
\hline Título & Número de amostras & Título & Número de amostras \\
\hline$<40$ & 35 & $<25$ & 86 \\
\hline 40 & 11 & 25 & 7 \\
\hline 80 & 5 & 50 & 2 \\
\hline 160 & 16 & 100 & 3 \\
\hline 320 & 14 & 200 & 1 \\
\hline 640 & 15 & 400 & - \\
\hline 1280 & 3 & 800 & 1 \\
\hline 2560 & 1 & 1600 & - \\
\hline
\end{tabular}

$\mathrm{N}+100$

Andreotti et al. (2005), na área urbana de Campo Grande, MS, encontraram soroprevalência de $29 \%$ para Leishmania spp. e $27,2 \%$ para $N$. caninum, indicando que ambas as infecções são comuns nos cães da região, embora a infecção por Leishmania spp. não tenha aumentado significativamente a susceptibilidade para a infecção simultânea por N. caninum.

Os cães representam papel importante no ciclo epidemiológico de ambas as doenças. Em áreas não endêmicas, é importante manter a vigilância sorológica dos cães e entomológica dos vetores, para detectar precocemente alterações epidemiológicas locais. Savani et al. (2005) relataram coinfecção por Leishmania (Leishmania) chagasi e Trypanossoma (Trypanozoon) evansi em um cão, fato que desperta o interesse para as reações cruzadas, que geram resultados sorológicos não confiáveis, o que reforça a hipótese de que a imunossupressão na leishmaniose pode predispor o animal a outras infecções. Independente de não se ter encontrado associação entre as duas enfermidades, elas devem ser consideradas como importantes do ponto de vista de saúde animal e de saúde pública.

Palavras-chave: cão, Neospora caninum, Leishmania spp., anticorpo

\begin{abstract}
The survey analyzed 100 samples of serum collected from dogs at the Center for Zoonoses Control of Bauru, randomly chosen. In the study, 65\% of the samples were positive for leishmaniasis and $14 \%$ for neosporosis. The association between the presence of antibodies by the reaction of indirect immunofluorescent antibody test (IFAT) in the detection of anti-Leishmania and anti-Neospora antibodies was examined by the Fischer Exact Test $(P=0.41)$, indicating no association between the results for Leishmania $s p$. and Neospora caninum $(\alpha=0.05)$. The absolute frequencies of the IFAT in the detection of antibodies anti-Leishmania and anti-Neospora caninum were analyzed using the Spearmann correlation coefficient for Leishmania and $\mathrm{N}$. caninum titters, $r=0.0975$ and $P=0.33$, which did not indicate significant correlation between the titters for both pathogens.
\end{abstract}

Keywords: dog, Neospora caninum, Leishmania spp., antibodies

\section{REFERÊNCIAS BIBLIOGRÁFICAS}

ANDREOTTI, R.; OLIVEIRA, J.M.; SILVA, E.A. et al. Occurrence of Neospora caninum in dogs and its correlation with visceral leishmaniasis in the urban area of Campo
Grande, Mato Grosso do Sul, Brazil. Vet. Parasitol., v.135, p.375-379, 2005.

BJERKAS, I.; JENKINS, M.C.; DUBEY, J.P. Identification and characterization of Neospora caninum tachyzoite antigens useful for diagnosis 
of neosporosis. Clin. Diag. Lab. Immunol., v.16, p.214-221, 1994.

CAMARGO, M.E. Fluorescent antibody test for the serodiagnosis of American trypanossomiasis: technical modification employing preserved culture forms of Trypanossoma cruzi in a slide test. Rev. Int. Med. Trop. São Paulo, v.8, p.227234, 1966.

CRINGOLI, G.; RINALDI, L.; CAPUANO, F. et al. Serological survey of Neospora caninum and Leishmania infantum co-infection in dogs. Vet. Parasitol., v.106, p.307-313, 2002.

DITTRICH, R.L. Diagnóstico sorológico, isolamento, cultivo e caracterização molecular de Neospora caninum em bovinos leiteiros $e$ equinos no estado do Paraná, Brasil. 2002. 184f. Tese (Doutorado) - Setor de Tecnologia, Universidade Federal do Paraná, Curitiba.

DUBEY, J.P.; HATTEL, A.L.; LINDSAY, D.S. et al. Neonatal Neospora caninum infection in dogs: Isolation of the causative agent and experimental transmission. J. Am. Vet. Med. Assoc., v.193, p.1259-1263, 1988.
LAINSON, R.; SHAW, J.J. Evolution, classification and geographical distribution, In: PETERS, W.; KILLICK-KENDRICK, R. (Eds). The leishmaniases in biology and medicine. Londres: Academic, 1987. v.1, p.1-120.

TARANTINO, C.; ROSSI, G.; KRAMER, L.H. et al. Leishmania infantum and Neospora caninum: simultaneous skin infection in a young dog in Italy. Vet. Parasitol., v.102, p.77-83, 2001.

TRIOLA, M.F. Introdução à estatística. 9.ed. Rio de Janeiro: LTC, 2005. 682p.

SAVANI, E.S.M.M.; NUNES, V.L.; GALATI, E.A.B. et al. Occurrence of coinfection by

Leishmania (Leishmania) chagasi and Trypanossoma (Trypanozoon) evansi in a dog in the state of Mato Grosso do Sul, Brazil. Mem. Inst. Oswaldo Cruz, v.100, p.730-741, 2005. 